\title{
ANTIPROMASTIGOTE AND CYTOTOXIC ACTIVITIES OF FLAVONOIDS FROM Fridericia speciosa LEAVES
}

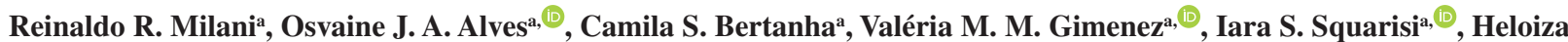

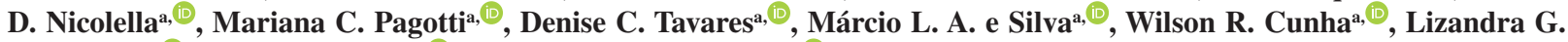
Magalhães $^{\mathrm{a},(1)}$, Ana H. Januario ${ }^{\mathrm{a},(\mathbb{1}}$ and Patricia M. Paulettia,*,(1)

aNúcleo de Pesquisa em Ciências Exatas e Tecnológicas, Universidade de Franca, 14404-600 Franca - SP, Brasil

Recebido em 26/04/2020; aceito em 04/08/2020; publicado na web em 04/09/2020

\begin{abstract}
Fridericia speciosa (Bignoniaceae) is a liana that occurs in humid to dry vegetation in eastern and southeastern Brazil. Species belonging to the genus Fridericia are employed as medicinal plants. This study evaluates the antipromastigote and cytotoxic activities of the crude extract, fractions, and compounds isolated from F. speciosa, and an HPLC (High-Performance Liquid Chromatography) analytical method was used to quantify the bioactive flavonoids. The flavonoids alpinetin (1), luteolin (2), diosmetin (3), and apigenin (4) were isolated from the active EtOAc-soluble fraction (EAF) of the crude ethanol extract (LCE) obtained from F. speciosa leaves. Both LCE and EAF were active against the normal human lung fibroblast cell line GM07492A ( $\mathrm{IC}_{50}$ of $460.7 \mu \mathrm{g} \mathrm{mL} \mathrm{L}^{-1}$ and $381.4 \mu \mathrm{g} \mathrm{mL}^{-1}$, respectively). Only EAF showed activity against Leishmania amazonensis $\left(80.4 \%\right.$ at $\left.50 \mu \mathrm{g} \mathrm{mL} \mathrm{m}^{-1}\right)$. Compounds $\mathbf{1}$ and 2 were quantified by HPLC-DAD in both LCE $(\mathbf{1}: 6.21 \% ; \mathbf{2}: 1.11 \%)$ and $\operatorname{EAF}(\mathbf{1}: 45.32 \% ; \mathbf{2}: 2.00 \%)$. At $100 \mu \mathrm{M}$, compounds $\mathbf{1}-\mathbf{4}$ inhibited $L$. amazonensis flagellar motility by $40.2 \%, 26.8 \%, 1.0 \%$, and $24.8 \%$, respectively, while their toxicities $\left(\mathrm{IC}_{50}\right)$ to the normal cell were $>1000,353.0,766.2$, and $>1000 \mu \mathrm{gL}^{-1}$, respectively. Therefore, F. speciosa leaves are a prolific source of bioactive flavonoids.
\end{abstract}

Keywords: antipromastigote activity; cytotoxic activity; flavonoids; Fridericia speciosa; HPLC-DAD.

\section{INTRODUCTION}

Fridericia speciosa Mart (Bignoniaceae), synonymies Fridericia guilielma Mart and Tabebuia sanguinea DC, is popularly known as "cipó-quebrador" and is found in humid to dry vegetation in eastern and southeastern Brazil. The genus Fridericia belongs to the tribe Bignonieae and includes sixty-seven species, ${ }^{1}$ some of which, such as F. chica, are employed in folk medicine to treat syphilis and eye ailments, to prevent caries, and to keep the skin soft and moist. ${ }^{2}$ The Agência Nacional de Vigilância Sanitária (ANVISA, National Health Surveillance Agency in Brazil) included $F$. chica in the list of plants with interest to Sistema Único de Saúde (SUS, The Brazilian Public Health System). ${ }^{3}$ Additionally, the World Health Organization (WHO) has been promoting the use of traditional medicine, which should provide safety, effectiveness, and good quality. ${ }^{4}$

Leishmaniasis is a parasitic disease that is transmitted by phlebotomine sand flies and which is caused by parasites from the genus Leishmania. Three forms of leishmaniasis affect patients: visceral, cutaneous, and mucocutaneous leishmaniasis. Cutaneous leishmaniasis is the most common form of the disease, and in 2018, 253,435 new cases were reported globally, and $18 \%$ of these cases occurred in the Americas. Brazil was among the seven American countries that recorded these cases, reporting over 10,000 new cases. ${ }^{5}$ Treatment for leishmaniasis has relied on antileishmanial drugs, mainly antimoniate derivatives, amphotericin $\mathrm{B}$, paromomycin, pentamidine isethionate, miltefosine, and azole compounds, but cases of parasite resistance to these drugs have been cause for concern. ${ }^{6}$

In this context, as part of our ongoing biological studies on Bignonieae species, ${ }^{7-9}$ and given the potential medicinal uses of Fridericia, we have screened the crude ethanol extract obtained from $F$. speciosa leaves and the corresponding fractions against Leishmania amazonensis promastigote forms, the etiological agent of cutaneous and mucocutaneous leishmaniasis in Brazil. We have

*e-mail: patrícia.pauletti@unifran.edu.br determined the chemical composition of the most active fraction by isolating its compounds. In addition, we have employed an HPLC (High-Performance Liquid Chromatography) analytical method to quantify the bioactive flavonoids. Finally, bearing in mind that studies on cytotoxicity assays based on cell cultures are essential for evaluating the toxicity, antiproliferative action, and chemopreventive efficacy of potential anti-cancer compounds that could overcome the lack of selectivity and the adverse side effects of the currently accessible anti-cancer therapies, and given that such assays are frequently applied for materials from plant origin, like extracts, fractions, and isolated compounds, we have investigated the cytotoxicity of EAF and compounds $\mathbf{1}-\mathbf{4}$ against a normal cell line to obtain information about their safety. ${ }^{10-13}$

\section{EXPERIMENTAL SECTION}

\section{General procedures}

The solvents employed in this work were analytical grade and were purchased from Synth or they were HPLC grade and acquired from J. T. Baker. Ultrapure water was obtained from Direct-Q-UV Millipore. The Sephadex LH-20 column SR 25/100 was coupled to a peristaltic pump model P-1 with flow of $2 \mathrm{~mL} \mathrm{~min}^{-1}$, and a fraction collector model Frac-920 was used to obtain the subfractions; all the equipment was purchased from GE Healthcare. Sigma-Aldrich silica gel plates in aluminum foil with fluorescent indicator were employed for TLC analysis, revealed by vanillin/sulfuric acid reagent and/or UV light (254/365 nm). Preparative TLC was conducted with silica gel 60 GF254 acquired from Sigma-Aldrich by using a spreader and plate thicknesses of $1.0 \mathrm{~mm}$. The solutions were concentrated in a Büchi rotary evaporator or in a Thermo Scientific speedvac vacuum concentrator. The flavonoids were quantified on a Shimadzu LC20AD HPLC system equipped with a Phenomenex Kinetex C18 column $(100 \times 4.60 \mathrm{~mm}, 2.6 \mu \mathrm{m})$. The NMR spectra were recorded on Bruker Advance DRX 400 and/or 500 spectrometers operating at 
400 or $500 \mathrm{MHz}$ for ${ }^{1} \mathrm{H}$ and at $100 \mathrm{MHz}$ for ${ }^{13} \mathrm{C}$; DMSO- $d_{6}$ (SigmaAldrich) and TMS were used as solvent and internal standard, respectively.

\section{Plant material}

Fridericia speciosa leaves were collected in February 2014 in Ribeirão Preto, São Paulo, Brazil (21 8.942” S, $47^{\circ} 44.082$ ” W). A voucher specimen (SPFR 16257) was deposited at the Herbarium of the Department of Biology, Laboratory of Plant Systematics, Faculty of Philosophy, Sciences and Letters of Ribeirão Preto, University of São Paulo, Brazil (Herbarium, SPFR). The licenses of the collected plant material were SISBIO \#42929-3 and COTEC \#SMA-260108$009.545 / 2015$, and the license to access genetic heritage was SisGen \#A1484F8.

\section{Isolation of flavonoids}

The leaves were air-dried, grounded $(1.16 \mathrm{~kg})$, and extracted with ethanol $(95 \%)$ by static maceration (1:4 w/v, three days, room temperature). After the solvent was evaporated, $29.5 \mathrm{~g}$ of crude extract (LCE) was achieved. Subsequently, $20 \mathrm{~g}$ of LCE was diluted in methanol/water $(2: 8, \mathrm{v} / \mathrm{v}, 500 \mathrm{~mL})$ and extracted with $n$-hexane $(3 \times 300 \mathrm{~mL})$ and ethyl acetate $(3 \times 300 \mathrm{~mL})$. Then, the methanol that was present in the methanol/water phase was removed in a rotary evaporator, and the remaining solution was extracted with $n$-butanol ( $3 \times 300 \mathrm{~mL})$. After that, the solvent was removed, and the $n$-hexane(5.8 g, HF), ethyl acetate- (5.2 g, EAF), $n$-butanol- (3.3 g, BF), and water- $(4.6 \mathrm{~g}, \mathrm{AF})$ soluble fractions were obtained. Next, EAF $(1.4 \mathrm{~g})$ was dissolved in methanol $(20 \mathrm{~mL})$ and purified on a Sephadex LH-20 column by using methanol as eluent, which provided 96 subfractions of $10 \mathrm{~mL}$ each. After that, the obtained subfractions were investigated by TLC with chloroform/methanol (9:1 v/v) and chloroform/ methanol/water $(43: 37: 20 \mathrm{v} / \mathrm{v} / \mathrm{v})$ as eluent, and they were grouped into 72 subfractions on the basis of similarity. Subfractions $35-37$ (139 mg, 93.3\% purity) and 69-78 (51 mg, 95.3\% purity) furnished compounds 1 and 2, respectively. Subfractions 49-59 (117 mg) were purified by preparative TLC with chloroform/methanol (9:1, v/v) as mobile phase, which yielded six subfractions. Subfractions 3 and 4 furnished compounds 3 (5 mg, 70.6\% purity) and 4 (20 mg, 89.7\% purity), respectively. The purity of the compounds was determined by HPLC-DAD.

\section{Quantification of flavonoids by HPLC}

The HPLC parameters were oven temperature of $40{ }^{\circ} \mathrm{C}$; flow rate of $0.6 \mathrm{~mL} \mathrm{~min}^{-1}$; mobile phase consisting of methanol (A) and water $+0.4 \%$ formic acid (B) gradient from 20 to $100 \%$ A for 30 min, which was followed by $100 \%$ A for $5 \mathrm{~min}$; detector wavelength at 286 and $254 \mathrm{~nm}$ for compounds $\mathbf{1}$ and 2, respectively; and C18 column. The DAD detector allowed us to verify peak purity by UV spectrum data generated during the analytical run of the extract and fraction, thus confirming that no other compound co-eluted with flavonoids $\mathbf{1}$ and $\mathbf{2}$. The retention time of the isolated compounds was used to identify the compounds in the chromatogram of the analyzed samples. The calibration standards $(0.8,2,5,10,25$, and $\left.50 \mu \mathrm{g} \mathrm{mL}^{-1}\right)$ were prepared by diluting stock solutions of flavonoids 1 and $2\left(500 \mu \mathrm{g} \mathrm{mL}^{-1}\right)$ in methanol. The calibration curves $(n=3)$ were obtained with the Excel software. The limits of detection and quantification (LOD and LOQ) were calculated by using the standard error of the response and the slope of the calibration curves. The leaf crude ethanol extract (LCE) and the ethyl acetate-soluble fraction (EAF) were weighed (3.12 $\mathrm{mg}$ and $1.96 \mathrm{mg}$, respectively), dissolved in methanol $(1000 \mu \mathrm{L})$, filtered through a PTFE syringe filter (13 mm, $0.2 \mu \mathrm{m}$, Merck Millipore), and injected ( $20 \mu \mathrm{L}$ ) into the HPLC system.

\section{In vitro bioassays}

The activity against L. amazonensis promastigote forms (IFLA/ $\mathrm{BR} / 67 / \mathrm{PH} 8$ ) was determined by means of a previous methodology. ${ }^{14}$ The samples were dissolved in DMSO and culture medium; the maximum percentage of DMSO was $0.1 \%$. The evaluated concentrations were $50 \mu \mathrm{g} \mathrm{mL} \mathrm{m}^{-1}$ for the extract and fractions, and between 6.25 and $100 \mu \mathrm{mol} \mathrm{L} \mathrm{L}^{-1}$ for the isolated compounds. The negative control was RPMI 1640 medium containing $0.1 \%$ DMSO. The positive control was $1.56 \mu \mathrm{mol} \mathrm{L}^{-1}$ amphotericin B.

Cytotoxicity against the normal human lung fibroblast cell line (GM07492A) was assessed by the XTT assay. ${ }^{12}$ The extract, fractions, and compounds were dissolved in DMSO and culture medium; the maximum percentage of DMSO was $0.4 \%$. The tested concentrations ranged from 2.44 to $2500 \mu \mathrm{g} \mathrm{mL} \mathrm{m}^{-1}$ for the extract and fractions and from 7.81 to $1000 \mu \mathrm{g} \mathrm{mL} \mathrm{m}^{-1}$ for the isolated compounds. Negative (solvent $+0.4 \%$ DMSO) and positive (25\% DMSO) controls were also employed. The $50 \%$ growth inhibition concentration values $\left(\mathrm{IC}_{50}\right)$ were determined by non-linear regression curves obtained with GraphPad Prism version 6.0.

\section{RESULTS AND DISCUSSION}

The bioactivities of the crude ethanol extract of $F$. speciosa leaves (LCE) and its $n$-hexane- (HF), ethyl acetate- (EAF), $n$-butanol- (BF), and water- $(\mathrm{AF})$ soluble fractions were evaluated. The results depicted in Table 1 show that LCE was inactive against L. amazonensis promastigote forms and weakly active against human lung fibroblast cells. $\mathrm{HF}, \mathrm{BF}$, and $\mathrm{AF}$ were also inactive against $L$. amazonensis, while $\mathrm{BF}$ and $\mathrm{AF}$ were inactive against human lung fibroblast cells and $\mathrm{HF}$ displayed higher $\mathrm{IC}_{50}$ values against the latter cells. In contrast, EAF presented antipromastigote activity and was cytotoxic against human lung fibroblast cells, but this cytotoxic action was weak. Therefore, compared to LCE and the other soluble fractions, EAF provided better results concerning the investigated activities.

The active soluble fraction (EAF) furnished alpinetin (1), ${ }^{15}$ luteolin (2), ${ }^{16}$ diosmetin (3), ${ }^{17}$ and apigenin (4) ${ }^{18}$ (Figure 1), which were identified by NMR data (Supplementary material) and comparison with literature data. The methoxyl group in compound $\mathbf{3}$ could be located at C-7, C-4', or C-5'. Analysis of the ${ }^{1} \mathrm{H}$ NMR spectrum obtained for compound $\mathbf{3}$ and comparison with the chemical shifts values obtained for compound 2 revealed a variation in the chemical shifts of H-6' $(\Delta \delta 0.15)$ and $\mathrm{H}-2^{\prime}(\Delta \delta 0.16)$ in ring $\mathrm{B}$, which allowed us to establish that the methoxyl group was positioned in ring $\mathrm{B}$. Additionally, the relative position of the signals obtained for H-2' and H-6', which appeared at $\delta$ between 7.2 and 7.9 can help to differentiate between 3'-methoxy-4'-hydroxy and 4'-methoxy3'-hydroxy in ring B. The H-2' signal usually emerges at slightly higher field than the H-6' signal for structures that present a methoxyl group at C-4', whereas the position of the H-2' signal is reversed when the methoxyl is at C-3 ${ }^{\prime}{ }^{19}$ Here, the $\mathrm{H}-6$ ' and $\mathrm{H}-2$ ' signals arose at $\delta 7.55$ and 7.54, respectively, which matched the first situation. On the basis of these observations, we concluded that the methoxyl group was positioned at C-4' in compound $\mathbf{3}$.

At 50 and $100 \mu \mathrm{mol} \mathrm{L}^{-1}$, compounds $\mathbf{1}-\mathbf{4}$ inhibited L. amazonensis flagellar motility to some extent (Table 1 ). The $\mathrm{IC}_{50}$ values against the normal cells were higher than $1000 \mu \mathrm{mol} \mathrm{L}^{-1}$, which indicated the low toxicity of the isolated compounds toward human lung fibroblast cells. It is noteworthy that the antipromastigote activity 
Table 1. In vitro effects of the Fridericia speciosa leaf crude extract, soluble fractions, and compounds 1-4 against Leishmania amazonensis and GM07492A cells

\begin{tabular}{|c|c|c|c|c|c|c|c|c|}
\hline \multirow[t]{2}{*}{ Samples } & \multicolumn{6}{|c|}{$\begin{array}{l}\text { L. amazonensis promastigote in } 24 \mathrm{~h}^{\mathrm{a}} \\
\% \text { of flagellar motility inhibition } \pm \text { S.D. }\end{array}$} & \multicolumn{2}{|c|}{$\begin{array}{l}\mathrm{IC}_{50} \pm \mathrm{SD}^{\mathrm{b}} \\
\text { cell viability }\end{array}$} \\
\hline & $50 \mu \mathrm{g} \mathrm{mL}^{-1}$ & $100 \mu \mathrm{M}$ & $50 \mu \mathrm{M}$ & $25 \mu \mathrm{M}$ & $12.5 \mu \mathrm{M}$ & $6.25 \mu \mathrm{M}$ & $\left(\mu \mathrm{g} \mathrm{mL} L^{-1}\right)$ & $(\mu \mathrm{M})$ \\
\hline LCE & n.a. ${ }^{c}$ & - & - & - & - & - & $460.7 \pm 2.8$ & - \\
\hline $\mathbf{H F}$ & n.a. & - & - & - & - & - & $762.7 \pm 7.4$ & - \\
\hline EAF & $80.4 \pm 4.5$ & - & - & - & - & - & $381.4 \pm 29.9$ & - \\
\hline BF & n.a. & - & - & - & - & - & $>2500$ & - \\
\hline $\mathbf{A F}$ & n.a. & - & - & - & - & - & $>2500$ & - \\
\hline 1 & - & $40.2 \pm 1.1$ & $25.8 \pm 3.9$ & $0.7 \pm 1.0$ & $2.2 \pm 3.1$ & $0.2 \pm 0.3$ & $>1000$ & $>3704$ \\
\hline 2 & - & $26.8 \pm 2.5$ & $17.2 \pm 1.1$ & $0.0 \pm 0.0$ & $0.7 \pm 1.0$ & $6.1 \pm 8.6$ & $353.0 \pm 40.3$ & $1234.3 \pm 140.9$ \\
\hline 3 & - & $1.0 \pm 1.4$ & $0.8 \pm 1.2$ & $2.3 \pm 3.2$ & $4.0 \pm 0.9$ & $0.0 \pm 0.0$ & $766.2 \pm 50.0$ & $2554.1 \pm 166.7$ \\
\hline 4 & - & $24.8 \pm 4.1$ & $23.9 \pm 5.6$ & $2.7 \pm 0.5$ & $1.9 \pm 2.7$ & $3.2 \pm 4.5$ & $>1000$ & $>3704$ \\
\hline
\end{tabular}


blasts) growth inhibition after treatment for 24 h. cn.a. not active. Average data of two and/or three independent experiments.<smiles>COc1cc(O)cc2oc(-c3ccccc3)cc(=O)c12</smiles><smiles>[R20]Oc1ccc(-c2cc(=O)c3c(O)cc(O)cc3o2)cc1Br</smiles>

$$
\begin{array}{ll}
2 & \mathrm{R}_{1}=\mathrm{OH} ; \mathrm{R}_{2}=\mathrm{H} \\
3 & \mathrm{R}_{1}=\mathrm{OH} ; \mathrm{R}_{2}=\mathrm{CH}_{3} \\
4 & \mathrm{R}_{1}=\mathrm{H} ; \mathrm{R}_{2}=\mathrm{H}
\end{array}
$$

Figure 1. Structures of the flavonoids alpinetin (1), luteolin (2), diosmetin (3), and apigenin (4) isolated from Fridericia speciosa

of compound 1 has not been reported yet. Looking at the chemical structure of the tested flavones, we were able to establish that the replacement of the hydroxyl group in ring $\mathrm{B}$ of compound 2 with the methoxyl group in ring B of compound 3 reduced the antipromastigote action. As for cytotoxicity toward normal cells, a tri-substituted aromatic ring B seemed to be important for this activity, as in the case of compounds $\mathbf{2}$ and $\mathbf{3}$. Nevertheless, the presence of the methoxyl group again implied in decreased activity when compounds $\mathbf{2}$ and $\mathbf{3}$ were compared. Flavonoids $\mathbf{2}$, $\mathbf{3}$, and $\mathbf{4}$ have been reported to possess inhibitory action against L. donovani amastigote forms of the strain MHOM/ET/67/L82, whilst compound $\mathbf{4}$ has been described to inhibit L. amazonensis promastigote and amastigote forms of the strain MHOM/BR/75/ LTB0016. ${ }^{20-22}$ In addition, orally administered compound $\mathbf{4}$ showed efficacy toward cutaneous leishmaniasis in infected BALB/c mice. ${ }^{22}$ Moreover, compounds 1-4 have been investigated in cytotoxic assays; for example, compound $\mathbf{1}$ presented $\mathrm{IC}_{50}$ in the range of 88.22 to $>148.15 \mu \mathrm{mol} \mathrm{L}{ }^{-1}$ against CEM/ADR5000 leukemia cells, hepatocarcinoma HepG2 liver cancer cells, CCRF-CEM leukemia cells, P-glycoprotein-expressing and multidrug-resistant CEM/ ADR5000 cells, and normal liver AML12 cells. ${ }^{23}$ Furthermore, compounds $2-\mathbf{4}$ at $25 \mu \mathrm{mol} \mathrm{L}{ }^{-1}$ were not cytotoxic against the human leukemia cell THP-1 line. ${ }^{24}$

According to the HPLC-DAD method, the peaks corresponding to compounds $\mathbf{1}$ and $\mathbf{2}$ emerged at $t_{\mathrm{R}} 21.73$ and $20.49 \mathrm{~min}$, respectively (Figures 2a-d). For these compounds (1 and 2), the method was linear in the range from 0.8 to $50 \mu \mathrm{g} \mathrm{mL}^{-1}$ at 286 and $254 \mathrm{~nm}$, respectively. The regression equations and the correlation coefficients $\left(\mathrm{r}^{2}\right)$ of compounds $\mathbf{1}$ and $\mathbf{2}$ were $\mathrm{y}=70068 \mathrm{x}-3291$ and 0.9995 , and $y=154811 x-26952$ and 0.9994 , respectively. The limits of detection (LOD) were 0.40 and $0.44 \mu \mathrm{g} \mathrm{mL}^{-1}$ for compounds 1 and $\mathbf{2}$, respectively, and the limits of quantification (LOQ) were 1.35 and $1.46 \mu \mathrm{g} \mathrm{mL}^{-1}$ for compounds $\mathbf{1}$ and $\mathbf{2}$, respectively.

Alpinetin (1) was present at $58.08 \mu \mathrm{g} \mathrm{mL}^{-1}(6.21 \%$ relative to the dried crude extract, SD $0.09 \%$ ), and luteolin (2) was present at $10.38 \mu \mathrm{g} \mathrm{mL}^{-1}(1.11 \%$ relative to the dried crude extract, SD $0.10 \%)$ in the crude extract. Furthermore, EAF contained compound $\mathbf{1}$ at $444.15 \mu \mathrm{g} \mathrm{mL}^{-1}$ (45.32\% relative to the dried fraction, SD $2.00 \%$ ) and compound 2 at $19.62 \mu \mathrm{g} \mathrm{mL}^{-1}$ (2.00\% relative to the dried fraction, SD 0.15). Thus, the EAF bioactivity could be related to the presence of compounds $\mathbf{1}$ and $\mathbf{2}$ given that the isolated compounds showed biological activities. EAF also gave high yields of compound $\mathbf{1}$.

\section{CONCLUSIONS}

Our study has contributed with additional knowledge about $F$. speciosa, a species belonging to the tribe Bignoniea (Bignoniaceae), which in turn had its genera reviewed. ${ }^{1}$ The ethyl acetate-soluble fraction from $F$. speciosa is a rich source of bioactive flavanones and flavones. The ethyl acetate-soluble fraction of $F$. speciosa leaves presents high alpinetin content. This fraction also displays antipromastigote and cytotoxic (against normal cells) activities. This is the first time that alpinetin has been tested against L. amazonensis promastigote forms. Furthermore, the bioassay results suggested that replacing the hydroxyl group with a methoxyl in flavone ring $\mathrm{B}$ decreases the antipromastigote effect and the cytotoxicity against normal cells.

\section{SUPPLEMENTARY MATERIAL}

NMR spectra and HPLC-DAD chromatograms of compounds 1-4 are available at http://quimicanova.sbq.org.br, in PDF format; access is free.

\section{ACKNOWLEDGMENTS}

The National Council for Scientific and Technological Development, Coordination of Superior Level Staff Improvement, and São Paulo Research Foundation (Grants 2015/04999-8, and 2017/24860-0) are acknowledged for fellowships. We also thank the São Paulo Research Foundation (Grant 2013/09280-6, and 2016/10313-4) for funding this study. 

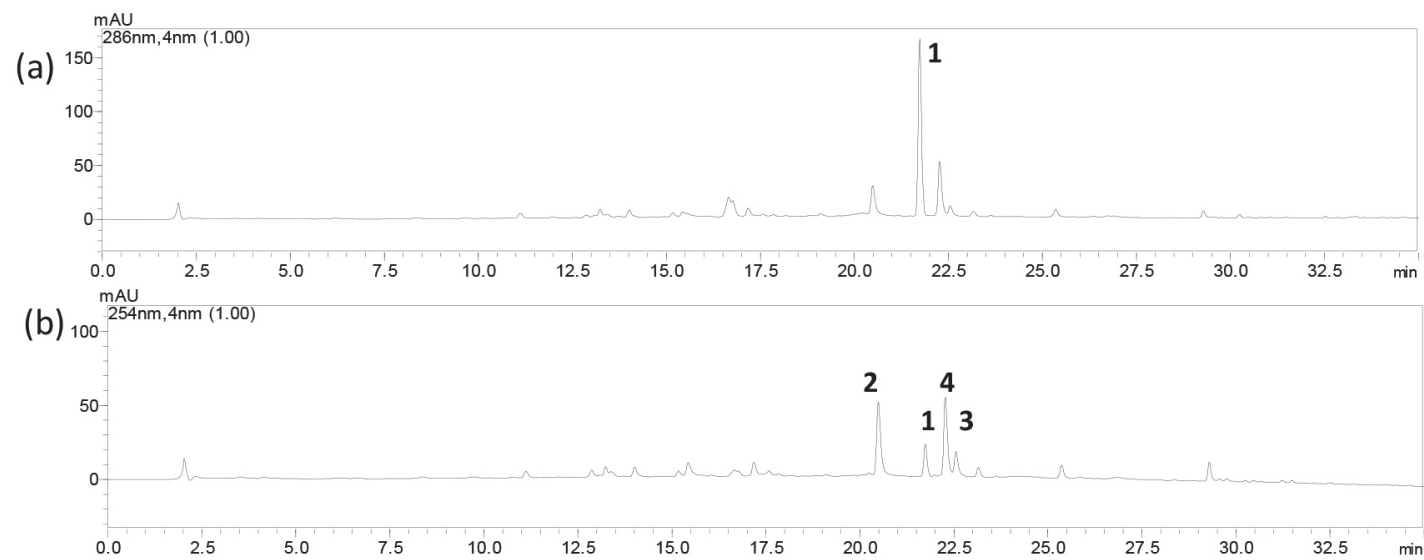

(c) $1000-286 \mathrm{~mm}, 4 \mathrm{~nm}(1.00)$
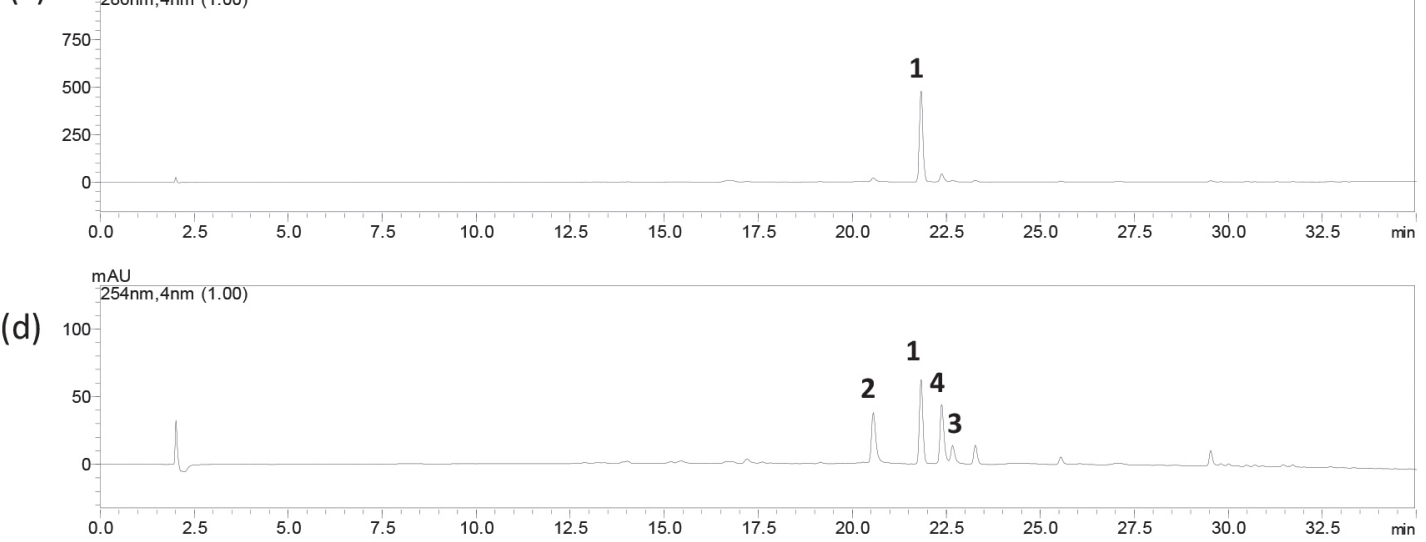

Figure 2. HPLC-DAD chromatogram of (a) the ethanol extract of Fridericia speciosa leaves at $\lambda=286 \mathrm{~nm}$; (b) the ethanol extract of $F$. speciosa leaves at $\lambda=254 \mathrm{~nm} ;(\mathrm{c})$ the ethyl acetate-soluble fraction of $F$. speciosa leaves at $\lambda=286 \mathrm{~nm}$; and (d) the ethyl acetate-soluble fraction of $F$. speciosa leaves at $\lambda=254 \mathrm{~nm}$. Chromatographic conditions: oven temperature $=40^{\circ} \mathrm{C}$, flow $=0.6 \mathrm{~mL} \mathrm{~min}{ }^{-1}$, mobile phase $=$ methanol $(A)$ and water $+0.4 \%$ formic acid $(B)$ gradient from 20 to 100\% A for $30 \mathrm{~min}, 100 \%$ A for $5 \mathrm{~min}$, and Phenomenex Kinetex C18 column. Compounds: alpinetin (1), luteolin (2), diosmetin (3), and apigenin (4)

\section{REFERENCES}

1. Lohmann, L. G.; Taylor, C. M.; Ann. Mo. Bot. Gard. 2014, 99, 348.

2. Gentry, A. H.; Ann. Mo. Bot. Gard. 1999, 79, 53.

3. https://www.saude.gov.br/images/pdf/2014/maio/07/renisus.pdf, accessed in August 2020.

4. World Health Organization; WHO Global Report on Traditional and Complementary Medicine 2019, World Health Organization: Geneva, 2019.

5. Ruiz-Postigo, J. A.; Grouta, L.; Jain, S.; Weekly Epidemiological Record 2020, 95, 265.

6. Ghorbani, M.; Farhoudi, R.; Drug Des. Devel. Ther. 2017, 12, 25.

7. Alvarenga, T. A.; Bêdo, T. R. F. O.; Braguine, C. G.; Gonçalves, U. O.; Magalhães, L. G.; Rodrigues, V.; Gimenez, V. M. M.; Groppo, M.; Silva, M. L. A.; Cunha, W. R.; Januario, A. H.; Pauletti, P. M.; Int. J. Biotechnol. Wellness Ind. 2012, 1, 122.

8. Alvarenga, T. A.; Bertanha, C. S.; de Oliveira, P. F.; Tavares, D. C.; Gimenez, V. M. M.; Silva, M. L.; Cunha, W. R.; Januario, A. H.; Pauletti, P. M.; Nat. Prod. Res. 2015, 29, 1083.

9. Bertanha, C. S.; Gimenez, V. M. M.; Furtado, R. A.; Tavares, D. C.; Cunha, W. R.; Silva, M. L. A.; Januario, A. H.; Borges, A.; Kawano, D. F.; Parreira, R. L. T.; Pauletti, P. M.; J. Braz. Chem. Soc. 2020, 31, 849.

10. Saravanan, M.; Vahidi, H.; Medina Cruz, D.; Vernet-Crua, A.; Mostafavi, E.; Stelmach, R.; Webster, T. J.; Mahjoub, M. A.; Rashedi, M.; Barabadi, H.; Int. J. Nanomedicine. 2020, 15, 3577.

11. Amawi, H.; Ashby, C. R. Jr.; Tiwari, A. K.; Chin. J. Cancer. 2017, 36, 50 .

12. Adan, A.; Kiraz, Y.; Baran, Y.; Curr. Pharm. Biotechnol. 2016, 17, 1213.
13. Tonisi, S.; Okaiyeto, K.; Hoppe, H.; Mabinya, L. V.; Nwodo, U. U.; Okoh, A. I.; 3 Biotech. 2020, 10, 141.

14. Andrade, P. M.; Melo, D. C.; Alcoba, A. E. T.; Ferreira Júnior, W. G.; Pagotti, M. C.; Magalhães, L. G.; Santos, T. C. L. D.; Crotti, A. E. M.; Alves, C. C. F.; Miranda, M. L. D.; An. Acad. Bras. Cienc. 2018, 90, 2671.

15. Itokawa, H.; Morita, M.; Mihashi, S.; Phytochemistry 1981, 20, 2503.

16. Kim, J. H.; Cho, Y. H.; Park, S. M.; Lee, K. E.; Lee, J. J.; Lee, B. C.; Pyo, H. B.; Song, K. S.; Park, H. D., Yun, Y. P.; Arch. Pharm. Res. 2004, 27, 177.

17. Correia-da-Silva, M.; Sousa, E.; Duarte, B.; Marques, F.; Carvalho, F.; Cunha-Ribeiro, L. M.; Pinto, M. M.; J. Med. Chem. 2011, 54, 95.

18. Christophoridou, S.; Dais, P.; Anal. Chim. Acta 2009, 633, 283.

19. Mabry, T. J.; Markham, K. R.; Thomas, M. B.; The Determination and Interpretation of NMR Spectra of Flavonoids. Em: The Systematic Identification of Flavonoids. Springer, Berlin, Heidelberg, 1970, cap. VIII.

20. Tasdemir, D.; Kaiser, M.; Brun, R.; Yardley, V.; Schmidt, T. J.; Tosun, F.; Rüedi, P.; Antimicrob. Agents Chemother. 2006, 50, 1352.

21. Fonseca-Silva, F.; Canto-Cavalheiro, M. M.; Menna-Barreto, R. F.; Almeida-Amaral, E. E.; J. Nat. Prod. 2015, 78, 880.

22. Fonseca-Silva, F.; Inacio, J. D.; Canto-Cavalheiro, M. M.; MennaBarreto, R. F.; Almeida-Amaral, E. E.; PLoS Neglected Trop. Dis. 2016, 10, e0004442.

23. Kuete, V.; Nkuete, A. H.; Mbaveng, A. T.; Wiench, B.; Wabo, H. K.; Tane, P.; Efferth, T.; Phytomedicine 2014, 21, 1651.

24. Nile, S. H.; Keum, Y. S.; Nile, A. S.; Jalde, S. S.; Patel, R. V.; J. Biochem. Mol. Toxicol. 2018, 32, 10.1002/jbt.22002. 